\title{
PENGEMBANGAN MEDIA PADA PEMBELAJARAN KOSA KATA \\ BAHASA ARAB BERBASIS KOMPUTER MENURUT KONSEP TEKNOLOGI PEMBELAJARAN
}

\section{Moh. Iqbal Assyauqi}

\section{Dosen Jurusan Pendidikan Bahasa Arab}

Fak. Tarbiyah dan Keguruan IAIN Antasari

Jl. A. Yani Km. 4,5 Banjarmasin

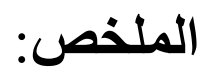

وإقامة تطوير الوسائط التعليمية لتعليم مفردات اللغة العربية

بمراحل آتية، و هي: تحليل الحاجات، و تصميم التطوير التعليمي، و تطوير المنتج، والمنتج الأول، والتقويم، والمنتج الأخير. وتحليل الحاجات هو خطوة أولى من تطوير الإنتاج بعني جمع المعلومات المناسبة بالإنتاج المتطور. تصديم التطوير التعليمي هو إثبات المهارة، وتتظبم إستر اتيجية التعليم، وتطوير المواد التعلبمبة، وتخطبط التقوبم.

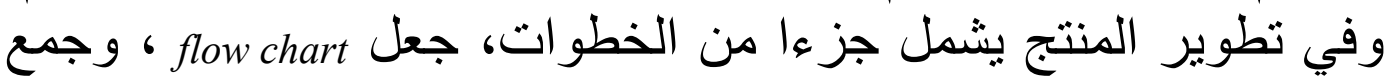
المواد المدعومة، وجعل story board 6 وإنتاج المنتج، وتقديم المواد المدعومة. و الإنتاج الأول هو نتيجة تطوبر المنتج الأول. وفي التقويم

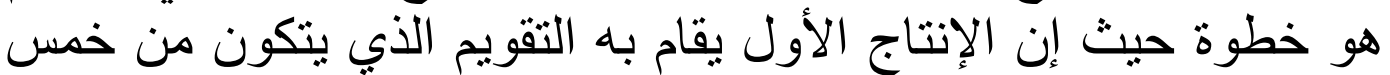
خطو ات، و هي تحكيم الخبر اء في الوسائل، وتحكيم الخبر اء في المو اده الاه و التجربة الفردية (فردان)، و التجربة في الفرقة (ستة أفر اد)، و التجربة المبدانية (25 فردا). وفي الإنتاج الأخير حيث إنه بهربه بهربه وبنتج وينثر إلى المجتمع الذين بحتاجون إلبه.

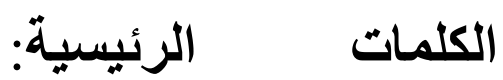




\section{A. Pendahuluan}

Bahasa Arab adalah bahasa Al-Qur'an dan Al-Hadits, keduanya adalah dasar agama Islam, bahasa kebudayaan Islam seperti filsafat, ilmu kalam, ilmu hadits, tafsir dan lain sebagainya serta bahasa komunikasi yang secara resmi digunakan oleh kurang lebih 20 negara. . Mempelajari bahasa asing, dalam hal ini bahasa Arab tidak semudah mempelajari bahasa ibu, banyak problematika yang harus dihadapi oleh seseorang yang sedang mempelajari bahasa tersebut. Adapun problematika tersebut menjadi dua, yaitu (1) bersifat linguistik, seperti mengenai tata bunyi, kosakata, tata kalimat, dan tulisan, dan (2) bersifat non linguistik, yang menyangkut segi sosio kultur atau sosial-budaya.

Kurikulum yang terlalu ideal dan berat untuk dilaksanakan sepenuhnya baik oleh guru maupun siswa, dimana siswa dituntut untuk menguasai bahasa Arab secara aktif dan pasif.Pengajar, mengingat begitu banyaknya materi pelajaran yang harus diselesaikan oleh siswa, wajar kalau kegiatan mengajar guru cenderung sekedar memenuhi target asal selesai (sebatas materi yang ditetapkan dalam kurikulum). Akibatnya peserta didik merasa terbebani oleh banyaknya materi yang dipaksakan, dan tentu saja pemahamannya tentang materi tersebut dangkal, karena proses belajar yang di ikuti tidak optimal.

Salah satu cara untuk mengatasi probleamtika tersebut yaitu dengan menggunakan media pembelajaran dalam mengajarkan kosa kata bahasa Arab. Dalam hal ini, media tersebut dibagi menjadi empat yaitu media visual, media audio, media audio visual, dan media terpadu (multimedia). Untuk mendapatkan media yang efektif dan efesian diperlukan beberapa langkah dalam mengembangkan media tersebut diataranya yang bisa kita singkat yaitu Perencanaan, Pengembangan dan Evaluasi.

\footnotetext{
${ }^{1}$ Azhar Arsyad, Bahasa Arab dan Metode Pengajarannya (Yogyakarta: Pustaka Pelajar, 2003), hlm. 1
} 


\section{B. Peranan Media dalam Pembelajaran}

Dalam proses pembelajaran, dua unsur yang amat penting adalah metode mengajar dan media pembelajaran. Kedua unsur ini saling berkaitan. Pemilihan salah satu metode mengajar tertentu akan mempengaruhi jenis media pembelajaran yang sesuai, meskipun ada aspek lain yang harus diperhatikan dalam memilih suatu media dalam pembelajaran. Seperti tujuan, jenis tugas, dan respon yang diharapkan pebelajar kuasai setelah pembelajaran berlangsung dan konteks pembelajaran termasuk karakteristik pebelajar. Meskipun demikian, dapat dikatakan bahwa salah satu fungsi utama media pembelajaran adalah sebagai alat bantu mengajar yang turut mempengaruhi iklim, kondisi, dan lingkungan belajar yang ditata diciptakan oleh guru ${ }^{2}$.

${ }^{2}$ Abdul Gafur, Peranan Teknologi Pembelajaran dalam Proses BelajarMengajar Ilmu Pengethuan Sosial. Pidato Pengukuhan Guru Besar dalam Bidang Ilmu Teknologi Pembelajaran Pengetahuan Sosial. Tidak di publikasikan, tahun 2004, hlm. 79

$\begin{array}{rrr}\text { Adanya } & \text { media } & \text { dalam } \\ \text { pembelajaran } & \text { adalah } & \text { untuk } \\ \text { merangsang } & \text { kegiatan } & \text { belajar. }\end{array}$

Dengan adanya interaksi antara pebelajar dengan media merupakan wujud nyata dari tindak belajar. Sementara, bentuk pembelajaran merupakan salah satu komponen dalam strategi penyampaian, apakah pebelajar dikelompokkan ke dalam kelompok besar, kecil, perseorangan atau mandiri.

Sebagai bagian dari sistem pembelajaran, media mempunyai nilai-nilai praktis yang berupa kemampuan atau ketrampilan untuk: (1) membuat konsep yang abstrak menjadi konkrit, misalnya sistem peredaran darah manusia; membawa obyek yang sukar didapat atau berbahaya ke dalam lingkungan belajar, seperti binatang buas; (3) menampilkan obyek yang terlalu besar ke dalam kelas, seperti candi, pasar; (4) menampilkan obyek yang tidak dapat dilihat oleh mata telanjang, seperti mikro organisme; (5) memungkinkan pebelajar mampu berinteraksi dengan lingkungan ${ }^{3}$.

3 Arief Sadiman dkk. Media pendidikan: Pengertian, pengembangan, 
Pengetahuan tentang fungsi dan kemampuan media merupakan hal yang sangat penting artinya apabila media merupakan bagian integral dari pembelajaran, karena dasar kebijakan dalam pemilihan, pengembangan, maupun pemanfaatan media tidak dapat terlepas dari pengetahuan ini.

\section{Konsep Pengembangan Menurut Teknologi Pembelajaran}

\section{Konsep}

pembelajaran teknologi perkembangan yang signifikan. Hal tersebut dapat dilihat dari definisidefinisi bidang teknologi pendidikan/pembelajaran sejak dari awal pertumbuhannya hingga dekade sekarang ini. Assocaition for Educational Communications and Technology (AECT) sebagai lembaga yang secara khusus berkecimpung dalam bidang pendidikan, komunikasi, dan teknologi, tercatat dua kali mengeluarkan definisi teknologi pembelajaran, yaitu definisi tahun 1977 dan tahun 1994.

dan pemanfaatannya (Jakarta: PT RajaGrafindo Persada, 2006), hlm. 16-17
Konsep

teknologi pembelajaran mutakhir dapat dilihat dalam definisi yang dikeluarkan pada tahun 1994, yaitu "Instructional Technology is the theory and practice of design, development, utilization, management, and evaluation of processes and reseorces for learning". 4

Kalau dicermati, perumusan definisi teknologi pembelajaran tahun 1994 lebih sederhana jika dibandingkan dengan definisi sebelumnya, yaitu definisi tahun 1977, yang berbunyi:

Instructional technology is a complex, integrated process involving people, procedures, ideas, devices, and organization, for analyzing problems, and devising, implementing, evaluating, and managing solutions to those problems, in situation in which learning is purposive and controlled. ${ }^{5}$

${ }^{4}$ Seels, B. B., \& Richey, R. C, Instructional technology: the definition and domain of the field. Washinton D.C.: Association for Educational Communication an Technology (AECT), 1994, hlm. 10

5 AECT "The Definition of Educational Technology : AECT Task Force on Definition and Terminology". Washington, DC : Associations for Educational Communications and Technology (AECT), 1997, hlm. 3 
Definisi tersebut dapat diperinci lagi menjadi beberapa komponen utama, yaitu: (1) riset dan teori; (2) desain, pengembangan, pemanfaatan, pengelolaan, dan evaluasi; (3) proses, sumber dan sistem; (4) belajar ${ }^{6}$.

Teknologi Pembelajaran adalah teori dan praktek dalam desain, pengembangan, pemanfaatan, pengelolaan dan penilaian proses dan sumber untuk belajar. Salah satu kawasan dari teknologi pembelajaran adalah kawasan pengembangan. Konsep pengembangan menurut teknologi pembelajaran adalah proses penerjemahan spesifikasi desain ke dalam bentuk fisik.Jadi dapat disimpulkan menurut teknologi pembelajaran, pengembangan adalah produksi media pembelajaran.

Kawasan pengembangan mencakup banyak variasi teknologi yang digunakan dalam pembelajaran. Kawasan pengembangan dapat diorganisasikan dalam empat kategori : teknologi cetak, teknologi audiovisual, teknologi berbasis komputer dan teknologi terpadu.

${ }^{6} \mathrm{Ibid}, \mathrm{hlm} .10$ a. Teknologi Cetak. Teknologi cetak adalah cara untuk memproduksi atau menyampaikan bahan, seperti buku-buku dan bahan-bahan visual yang statis, terutama melalui proses percetakan mekanis atau fotografis. Subkategori ini mencakup representasi dan reproduksi teks, grafis, dan fotografis.

b. Teknologi Audiovisual merupakan cara memproduksi dan menyampaikan bahan dengan mengunakan peralatan mekanis dan elektronis untuk menyajikan pesan-pesan audio dan visual. Pembelajaran audiovisual dapat dikenal dengan mudah karena menggunakan perangkat keras di dalam proses pengajaran.

c. Teknologi berbasis computer merupakan cara-cara memproduksi dan menyampaikan bahan dengan menggunakan pernagkat yang bersumber pada microprosesor. Teknologi ini dibedakan dari teknologi lain karena menyimpan informasi secara elektronis dalam bentuk digital, bukannya sebagai bahan cetak atau visual. 
Teknologi terpadu merupakan cara untuk memproduksi dan menyampaikan bahan dengan memadukan beberapa jenis media yang dikendalikan oleh komputer .?

Untuk bisa mengembangkan software pembelajaran berbasis komputer dengan baik maka perlu diperhatikan tahap-tahap yang harus dilalui sehingga tercipta suatu produk pembelajaran yang efektif. Tahap-tahap tersebut menurut Soulier 8 meliputi proses perencanaan, proses pengembangan, dan proses evaluasi. Tahap evaluasi diperlukan untuk menilai kualitas media yang dikembangakan untuk kemudian diadakan peningkatan kualitasnya

Rob Phillips mengemukakan ada empat tahapan dalam mengembangkan suatu multimedia yaitu pertama dimulai dari design yaitu tahap merencanakan proyek multimedia. Kedua develop, pada tahap ini terdapat tiga tahap pengembangan meliputi: tahap

${ }^{7}$ Ibid, hlm. 40-43

${ }^{8}$ Soenarto, S. \& Supriyadi E, .Relevanci pengembangan CAI dalam pendidikan. Cakrawala Pendidikan (Juni 2002.Th XXI. No.2), 2002, hlm. 186 praproduksi, tahap produksi dan tahap pascaproduksi. Ketiga evaluate, dan yang terakhir implemented.

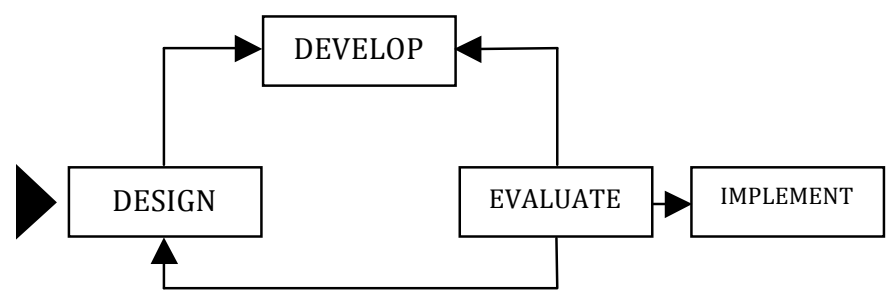

Gambar 2. Tahapan Pengembangan Multimedia ModelRob Philips ${ }^{9}$

\section{1) Design/Desain}

Desain dalam pengembangan multimedia pembelajaran merupakan suatu hal yang sangat penting untuk dilakukan. Pada tahap ini pengembang membuat spesifikasi secara rinci mengenai produk pembelajaran yang akan dibuat, spesifikasi hendaknya dibuat serinci mungkin, supaya pada tahap selanjutnya tidak diperlukan keputusan baru, tetapi menggunakan apa yang telah ditentukan pada tahap desain. Menarik tidaknya suatu produk yang dihasilkan dapat dilihat dari desain produk yang dibuat. Heinich, dkk menyatakan bahwa

9 Philips, R., Multimedia: A practical guide for educational application (London : Stirling (USA) : Kogen Page, 1997), hlm. 38 
beberapa hal yang perlu diperhatikan dalam merancang desain visual, yaitu:

a) Kejelasan tampilan visual

b) Energi yang diperlukan untul menginterprestasikan pesan

c) Keterbatasan keaktifan siswa dalam belajar

d) Fokus perhatian pada bagian penting dari pesan ${ }^{10}$

Simonson dan Thompson merekomendasikan beberapa elemen desain yang perlu diperhatikan, yaitu:

a) Knowledge of Correct Results, maksudnya bahwa dalam mendesain program multimedia pembelajaran harus menyertakan teknik indentifikasi, yaitu adanya tanda saat jawaban salah atau benar.

b) Feedback (umpan balik), yaitu pemberitahuan kepada siswa atau pengguna program. Sebagai contoh, ketika siswa selesai mengerjakan soal kuis atau evaluasi ada pemberitahuan

\footnotetext{
${ }^{10}$ Heinich, R., et al., Instructional media and technology for learning.Englewood Cliffts (4 ${ }^{\text {th }}$ ed.) (New Jersey: Prentice-Hall, Inc., A Simon \& Schuster Company, 1996), hlm..73-74
}

bahwa siswa telah menjawab dengan benar $75 \%$ item soal, sehingga ia boleh melanjutkan materi berikutnya, atau sebaliknya.

c) Branching (percabangan), yaitu rute yang diambil siswa dalam belajar.

d) Assessment (penilaian). Program pembelajaran yang baik harus ada penilaiannya, sehingga siswa mengetahui seberapa baik mereka menyelesaikan materi yang ada.

e) Advance organizers, maksudnya kemana siswa mengeksplorasi program sebaiknya ditunjukkan dalam pelajaran.

f) Prompt (pemberian petunjuk). Dengan adanya petunjuk yang jelas akan sangat membantu siswa memahami materi yang ada.

g) Screen design (desain layar). Resolusi layar menjadi pertimbangan utama ketika mendesain program pembelajaran. Jangan sampai jenis informasi yang disampaikan tidak jelas sehingga menyebabkan susah dibaca. 
h) Screen information (informasi layar). Tiga jenis informasi yang biasanya ada pada layar komputer adalah kata, gambar, dan ruang. Tiga komponen itulah yang digunakan untuk mendesain layar dengan memperhatikan prinsip-prinsip desain sehingga menjadi efektif. Misalnya gambar, gambar seharusnya didesain menurut level kenyataan yang dibutuhkan oleh level kemampuan siswa yang menggunakan.

i) Screen components (komponen layar). Yang penting diperhatikan dalam komponen layar ini adalah pertama, layar harus memberikan informasi orientasi kepada siswa. Informasi ini mungkin termasuk pernyataan kapan siswa masuk dalam pelajaran, sama dengan nomor halaman pada buku. Informasi ini biasa disebut sebaga "peta kognitif" pelajaran. Kedua, layar harus menyediakan sistem navigasi. Sistem ini memberikan kepada siswa bagaimana cara berpindah selama pelajaran, misalnya: membalik halaman atau perubahan layar. Ketiga, layar harus mampu menampilkan respon yang dibuat oleh siswa. Apa yang diketik siswa di keyboard atau diklik dengan mouse harus bisa ditampilkan oleh layar. Misalnya, tombol apa yang harus diklik untuk melewati sebuah halaman, kembali ke halaman sebelumnya untuk review, untuk keluar atau ke menu utama, dan sebagainya. Beberapa poin tersebut akan membuat siswa merasa mengontrol bukan dikontrol oleh layar.

j) Readability (keterbacaan). Keterbacaan adalah tingkatan seberapa mudah rangkaian huruf itu dibaca. Resolusi layar bisa jadi berbeda-beda antara satu komputer dengan komputer lainnya. Resolusi layar biasaya lebih rendah dari pada halaman buku, oleh karenanya harus benar-benar diperhatikan bahwa apa yang ditulis bisa dibaca. Selain keterbacaan, seorang desainer juga harus memperhatikan legibility atau 
kejelasan suatu huruf, yaitu suatu tingkatan seberapa mudah orang mengenali huruf-huruf yang ada pada suatu typeface. Typeface adalahsuatu set karakter dengan ciri bentuk yang sama pada setiap karakter. Dalam typografi (seni merangkai huruf), faktor legibility merupakan bobot kualitas dari desain huruf tersebut. Ia meliputi tampilan bentuk fisik masingmasing karakter. ${ }^{11}$

\section{2) Development/Pengembangan}

Tahap produksi merupakan tahap di mana seluruh objek yang telah didesain disusun (assembly) agar dapat menjadi paket pembelajaran yang utuh, yang dapat digunakan dalam proses pembelajaran. Pada tahap produksi ini, perencanaan dalam desain dibuat ke dalam bentuk yang lebih nyata.

Pada tahap ini, mulai dibuat pendukung-pendukung yang dapat menarik perhatian dalam proses pembelajaran, misalnya pembuatan

${ }^{11}$ Simonson, M.R \& Thompson, A., Educational Computing Foundations. (New York : Macmillan Publish Company, 1994), hlm. 45-51 gambar (image), clip art, animasi, video, audio, dan lain-lain. Pembuatan ini berdasarkan flowchart view, struktur navigasi, atau diagram objek yang telah direncanakan dalam tahap desain. Kegiatan assembly ini dibantu dengan authoning tool yang banyak beredar di pasaran.

Setelah semua bahan terkumpul, dilanjutkan dengan mengembangkan produk.Menyusun materi software perlu melakukan langkah-langkah mengembangkan screen map dan jika dibutuhkan maka perlu menulis criterion frame. Setelah flowchart selesai maka mulai menyusun nakah materi pada setiap frame yang disebut screen map dan penulis materi sama persis seperti yang ditampilkan dimonitor. Selanjutnya menyiapkan pertanyaan yang didesain untuk mengukur pemahaman mahasiswa sebagai pemakai produk apakah telah mencapai kreteria pencapaian belajar dan siap pindah kemateri selanjutnya.

Langkah berikutnya adalah memasukkan materi ke authoring system. Menurut M. Suryangto (2005: 165) authoring merupakan 
aplikasi computer yang memberikan peluang kepada pemakai untuk mengembangkan sebuah perangkat lunak dengan dragging dan droping berbagai obyek multimedia tanpa harus mengetahui penggunaan atau pemahaman bahasan pemograman, meskipun ada beberapa authoring yang dilengkapi dengan bahasa pemograman, misalnya Macromedia director yang dilengkapi dengan lingo. ${ }^{12}$

\section{Untuk lebih lengkapnya}

langkah-langkah dalam pengembangan adalah sebagai berikut:

1) Pembuatan dan pengumpulan komponen

Tujuannnya adalah membuat dan mengumpulkan semua komponen yang digunakan.Sebagai inputnya adalah spesifikasi fungsi yang telah dibuat pada tahap sebelumnya. Tugas atau kegiatannya adalah pengetikan materi kosakata bahasa arab dalam format word kemudian di transfer ke painting dan kemudian diedit lagi melalui corel X3,

${ }^{12}$ Adi Kusrianto, Huruf Display dengan Komputer dan Manual.Yogyakarta: Andi, 2005), Hlm. 165 mengumpulkan image atau gambar, tombol, suara serta music penggiring dan lain-lain dari library atau sumber lainnya. Outputnya adalah semua komponen multimedia yang akan digunakan, dan naskah materi kosakata bahasa Arab.

2) Penyatuan komponen

Tujuannya adalah mengintegrasikan semua komponen kedalam screen. Sebagai inputnya adalah spesifikasi fungsi dan semua komponen yang akan digunakan dan yang telah dipersiapkan sebelumnya. Kemudian mentransfer materi kosakata bahasa Arab dalam format word ke dalam stage flash (format swf), mendistribusikan materi tersebutkedalam screen seperti yang terdapat dalam flowchart dan lay-out. Pada tahap ini semua materi yang ada disusun seperti gambar, animasi teks dan video disatukan.Sehingga outputnya adalahproduk awal yang masih berupa software pembelajaran.

3) Testing prototype/produk awal 
Tujuannya adalah mengetes produk awal, mengevaluasi, dan mengedentifikasi

kekurangannya.Sebagai inputnya adalah produk awal. Setelah di ujicobakan pada kelompok kecil dan mendapat masukan dari ahli materi dan ahli media, maka produk akan direvisi berdasarkan hasil ujicoba tersebut. Sehingga outputnya berupa CD pembelajaran yang memuat tentang pengajaran kosakata bahasa Arab melalui permainan bergambar.

\section{4) Evaluate/Evaluasi}

Evaluasi atau penilaian adalah pengambilan keputusan terhadap sesuatu diawali dengan pengukuran.Suharsimi

mengungkapkan bahwa penilaian dilakukan dengan maksud untuk melihat apakah usaha yang dilakukan melalui pembelajaran sudah mencapai tujuan ${ }^{13}$.Menurut Nana Sudjana inti dari penilaian adalah proses memberikan atau menentukan

13 Ade Kusnandar, Evaluasi Multimedia Pembelajaran. Modul serial pelatihan pengembangan multimedia untuk pembelajaran, Jakarta, Pustekkom Diknas, 2000, hlm. 3 nilai kepada objek tertentu berdasarkan kriteria yang telah ditentukan. ${ }^{14}$

Kemp membagi tahapan evaluasi menjadi 3 (tiga), yaitu: (1) one to one trials, (2) small-group trials, dan (3) field trials. Tahap pertamadilakukan pada tahap pengembangan yang dimaksudkan untuk try-out impressions dan diberikan kepada pebelajar secara individual, dan teknik pengukurannya dilakukan dengan cara observasi, survey, dan interview. Tahap kedua dilakukan pada tahap persiapan, dimaksudkan untuk mengetahui kelemahankelemahan dan kelebihan-kelebihan dari produk, diberikan kepada kelompok kecil berjumlah 8-20 siswa dengan teknik pengukuran menggunakan cara-cara observasi, sikap, dan performance. Tahap ketiga dilakukan saat produk jadi, dimaksudkan untuk penilaian produk, diberikan kepada siswa pada kelas reguler, dan teknik pengukuran

\footnotetext{
${ }^{14}$ Nana Sudjana, .Penilaian Hasil Proses Belajar Mengajar (Bandung : PT. Remaja Rosdakarya, 2002), hlm. 3
} 
yang utama menggunakan performance dan sikap. ${ }^{15}$

Hanafin mengemukakan ada dua tahapan dalam evaluasi sebuah multimedia pembelajaran yaitu; evaluasi formatif dan evaluasi sumatif. Evaluasi formatif lebih berorientasi pada tingkat kelayakan media yang dikembangkan sedangkan evaluasi sumatif lebih berorientsi pada tingkat efektivitas media itu digunakan sesuai dengan tujuan dan sasaran pembelajaran. Untuk mengetahui efektivitas media yang digunakan terhadap hasil belajar digunakan ujian atau test yaitu pre test dan post test. Menurut Philips ada beberapa hal yang perlu diketahui dalam evaluasi formatif diantaranya: efektivitas navigasi, apakah siswa atau pengguna nyaman dalam menggunakan media tersebut, desain layar efektif dan proses kerjanya terencana. Sedangkan alat pengumpul data berupa angket atau interview kepada ahli media, ahli materi dan pengguna atau siswa.

${ }^{15}$ Kemp, J. E. \& Dayton, D. K., Planning and producting instructional media $\left(4 t^{h}\right.$ ed.). (New York: Harper \& Row, Publisher, Inc, 1985), hlm. 285
Kriteria sebuah multimedia yang efektif menurut Hannafin adalah:

a) Berdasarkan pada tujuan pembelajaran, tujuan pembelajaran dapat membantu para pengembang dalam menentukan kegiatan atau produk yang tepat, lebih focus kepada topic yang dibutuhkan.

b) Sesuai dengan karakteristik pelajar, pembelajaran yang bagus didesain untuk subpopulasi yang spesifik. Langkah pertama adalah untuk memperkirakan ilmu pengetahuan dan tingkat pemahaman dan pengetahuan dari pelajar yang menjadi target, apabila pelajar tidak mempunyai ketrampilan atau pengetahuan yang dibutuhkan maka pembelajaran tersebut akan gagal.

c) Memaksimalkan interaksi, media yang baik adalah mengajak para pelajar lebih sering berinteraksi dengan media tersebut sehingga media tersebut bisa dikatakan interaktif.

d) Terindividualisasi, media komputer menyediakan pembelajaran yang lebih 
individual dimana pelajar bisa belajar sendiri dirumah tanpa bantuan guru dalam membimbing.

e) Menarik perhatian pelajar.

f) Menyenangkan.

g) Umpan balik, siswa seringkali membutuhkan suatu penghargaan atau umpat balik apabila mereka telah mengerjakan sesuatu dengan benar, seorang pengembang sebaiknya memberikan berbagai macam variasi dalam memberikan umpan balik.

h) Sesuai dengan lingkungan,

i) Evaluasi tampilan yang tepat.

j) Menggunakan sumber daya dengan bijaksana. Resolusi komputer sering menjadi hambatan dalam menampilkan gambar atau tulisan dengan optimal, oleh karena itu seorang pengembang harus bisa menempatkan suatu multimedia yang bisa digunakan di mana saja. $^{16}$

Adapun unsur-unsur pokok dalam penilaian kualitas dan daya

\footnotetext{
${ }^{16}$ Hanafin, M. J., Peck, (1988). The design development, and evaluation of instructional software. New York : Macmillan Publishing Company. Hal 135146
}

tarik program multimedia, beberapa ahli memberikan kriteria-kriteria yang bermacam-macam. Ade Koesnandar menyatakan ada 7 unsur dalam penilaian program multimedia, antara lain:

a) InstructionalDesign, mencakup: kelengkapan komponen instruksional, kejelasan tujuan, kejelasan uraian materi, pemberian latihan, pemanfaatan aspek-aspek pedagogis, ketepatan evaluasi, konsistensi antara tujuan, materi, dan evaluasi.

b) Content, mencakup: kebenaran isi, kecukupan materi, keluasan dan kedalaman, urgensi tiap materi, dan aktualitas (up to date).

c) Curriculum, mencakup: kejelasan sasaran, kejelasan tujuan pembelajaran, cakupan dan cukupan, struktur materi, ketepatan evaluasi, konsistensi antara tujuan, materi, dan evaluasi.

d) Communication, mencakup: struktur program (linier atau branching), penggunaan bahasa (verbal, visual, atau komunikatif), logika Berpikir pemrograman, interaktivitas, antisipasi respon 
dan respon terhadap respon, pemanfaatan karakteristik media, dan memberikan tantangan.

e) Cosmetic, mencakup: tampilan (screen design), grafis (terutama background), movie atau animasi, warna, suara, musik, navigasi, dan format sajian.

f) Compatibility, mencakup: keefektivitas dibanding media lain, kompatibel dengan software sebelumnya, dan user friendly.

g) Creativity, mencakup: sesuatu yang baru atau aktual, orisinil, dan unik atau berbeda. ${ }^{17}$

Sedangkan kriteria yang dievaluasi menurut Walker \& Hess antara lain:

a) Kualitas isi dan tujuan, meliputi: ketelitian dan kesaksamaan (accuracy), urgensi, kelengkapan (completeness), keseimbangan (balance), perhatian dan minat (interest), kewajaran (fairness), kepatutan atau kelayakan (appropriateness to user's situation).

b) Kualitas instruksional, meliputi: menyediakan kesempatan untuk belajar, menyediakan alat untuk belajar, kualitas motivasional,

${ }^{17}$ Ibid, hlm. 1 fleksibilitas instruksional, kenyamanan, kualitas sosial interaksi instruksional, kualitas penilaian dan testing, kemungkinan berpengaruh kuat atau dampaknya kepada siswa, kemungkinan berpengaruh kuat atau dampaknya pada guru dan pembelajaran.

c) Kualitas teknikal, meliputi: realibilitas (keterpercayaan), kesenangan menggunakan, kualitas tampilan, kualitas perlakuan jawaban, kualitas manajemen program, kualitas dokumentasi, kualitas-kualitas lain diatur khusus. ${ }^{18}$

Dengan berpedoman pada pengertian penilaian, maka sebuah media pembelajaran yang dikembangkan, selayaknya dilakukan penilaian untuk melihat apakah media tersebut tepat sasaran dan layak untuk digunakan, atau harus direvisi kembali sebelum digunakan, sehingga dapat mencapai tujuan yang telah ditetapkan. Dari beberapa kriteria di atas selanjutnya

${ }^{18}$ Kemp, J. E. \& Dayton, D. K., Opcit hal 206 
pengembang mengembangkannya menjadi kisi-kisi kuesioner.

\section{Pembelajaran Berbantuan Komputer Cai (Computer- Assisted Instruction)}

Metode pembelajaran berbantuan komputer adalah suatu cara yang dilakukan untuk memperoleh informasi yang mendukung proses kognitif yang diperlukan untuk pencapaian prestasi dan pemberian motivasi siswa melalui materi pelajaran yang ditayangkan dengan bantuan komputer. Menurut Gerlech \& Elly “.....a computer is a machine especially designed for the manipulation of code infomation, an automatic electronic machine for performing simple and complex operation. It operates with numbers expressed directly as unity in a decima, binary, or system.) $)^{19}$

Dalam pembelajaran berbantuan komputer, peserta belajar berhadapan langsung dengan komputer.Pembelajaran berbantuan

${ }^{19}$ Gerlach, V.S, Ely, D.P. Teaching and media a systematic approach $\left(2^{\text {nd }} \mathrm{ed}\right)$. Englewood Cliffs (New Jersey : Prentice Hall Inc., 1980), hlm. 393 komputer berangkat dari keterbatasan pembelajaran klasikal yang seringkali membuat siswa bosan dan juga untuk mengatasi rasio antara pengajar dan peserta belajar yang tidak seimbang.Berpijak pada keterbatasan pembelajaran klasikal, maka kemudian didesain sebuah alternative pembelajaran berbantuan komputer untuk dapat membantu mengatasi permasalahan tersebut.

Adapun prinsip-prinsip perancangan CAI adalah:

1. Belajar harus menyenangkan.

2. Interaktivitas.

3. Kesempatan berlatih harus memotivasi, cocok, dan tersedia feedback.

4. Menuntun dan melatih siswa dengan lingkungan informal ${ }^{20}$

Menurut Criswell tipe utama dalam pembelajaran berbantuan komputer ada 10 macam, yaitu: Lessons atau Tutorials, Reinforced Drill and Practice, Intelligent CBI, Training Simulations Instructional Games, Training Simulators, Expert Systems, Embedded Training,

20 Azhar Arsyad, Media Pembelajaran ( Jakarta: PT. Raja Grafindo Persada, 2002), Cet-3, hlm. 165-168 
Adaptive Testing, dan ComputerManaged Instruction. ${ }^{21}$

\section{E. Teori-Teori yang Mendukung Pembelajaran Berbantuan Komputer}

Bahwa penggunaan komputer dalam pembelajaran akan membuat pembelajaran menjadi efektif perlu didukung oleh teori-teori yang mendasarinya. Begitu juga sebaliknya, ketika komputer dan pembelajaran berbasis komputer tidak berjalan efektif dan seharusnya tidak digunakan.

\section{Teori Behaviorisme}

Behaviorisme dianggap mempunyai pengaruh paling besar terhadap teori-teori yang mendukung penggunaan komputer dalam pembelajaran. Behaviorisme banyak digunakan sebagai dasar untuk mendesain pembelajaran berbasis komputer model lama dan merupakan cikal bakal banyak strategi pembelajaran. Behaviorisme didasarkan atas prinsip bahwa

${ }^{21}$ Criswell, E.L., The design of computer-based instruction, (New York: Macmilan Publishing Company, 1989), hlm. 6 pendidikan harus didesain untuk menghasilkan tata perilaku yang bisa dilihat dan diukur. Ahli behaviorisme menganggap keadaan mental para siswa hanyalah sebuah kecenderungan untuk berperilaku. Karena keadaan mental tidak dapat dilihat, behaviorist tidak bisa mempercayai bahwa pembelajaran seharusnya tidak diarahkan untuk menghasilkan perilaku yang diinginkan dalam diri siswa. Dengan kata lain, behaviorist berharap agar kegiatan pembelajaran yang efektif, misalnya tutorial berbasis komputer, bisa mengubah siswa dengan cara yang jelas dan bisa diukur. Setelah melakukan pelajaran, siswa harus bisa melakukan apa yang sebelumnya tidak bisa dilakukan.

Koneksionisme ala Thorndike mengatakan bahwa pembelajaran didasarkan atas serangkaian asosiasi atau hubungan antara masalah pada situasi tertentu dan apa yang telah terselesaikan sebelumnya. Koneksionisme telah memberikan arah kepada B.F. Skinner dan juga merupakan cikal bakal munculnya gerakan pembelajaran terprogram. Penguatan dan perluasan 
koneksionisme digunakan untuk mendukung berbagai perubahan dalam pendidikan. Pertama, tujuan khusus pendidikan, seperti kemampuan membaca pada tingkatan tertentu, menjadi fokus dari kurikulum sekolah, daripada sekedar pembelajaran yang ditujukan memperkuat pikiran. Kedua, munculnya pengukuran akan hasil pendidikan. Terakhir koneksionisme mendorong para guru untuk memecah tugas-tugas rumit menjadi lebih sederhana dan untuk memberikan hadiah atas prestasi yang dibuat siswa dengan maksud untuk membangun ikatan atau hubungan antara situasi pembelajaran dan perilaku yang diinginkan. Beberapa konsep pemikiran tersebut yang menjadi dasar para ahli behaviorisme. Ide-ide tersebut juga digunakan dalam desain pembelajaran berbantuan komputer.

\section{Teori Sistem}

Simonson \& Thompson mengatakan bahwa teori sistem dikembangkan diparuh ketiga abad 20 sebagai akibat langsung dari meningkatnya nilai penting dan penerimaan akan sain dan metode ilmiah. Seiring dengan para ilmuan mulai memecahkan berbagai masalah dengan efektif, metode yang mereka gunakan kemudian dikaji secara luas dan diterapkan pada bidang yang baru. Teori sistem merupakan sebuah usaha untuk menggambarkan secara jelas prosedur untuk menjelaskan bagaimana kejadian di dunia nyata saling berkaitan. Ada sebuah hipotesis yang mengatakan bahwa prinsip-prinsip sistem bisa digunakan dalam keadaan apapun, tidak hanya keadaan yang melibatkan penelitian ilmiah atau pengembangan teknologi. Metode ilmiah membutuhkan kontrol untuk semua variasi potensial kejadian kecuali dua variasi, variabel yang sedang dikaji dan mempengaruhi pemikiran sesorang. Dengan ini, para ilmuan bisa mengamati fenomena dan berkomentar tentang bagaimana fenomena tersebut dipengaruhi. Jika seorang guru menyampaikan informasi di suatu kelas dengan menggunakan PBK dan menggunakan ceramah di kelas yang lain untuk melihat hasil yang dicapai oleh salah satu metode lebih baik 
daripada yang lain, maka guru tersebut sedang mempraktekkan semacam pengetahuan ilmiah yang dicetuskan oleh ahli teori sistem.

Pendekatan sistem pada pengembangan pembelajaran pada dasarnya merupakan serangkaian langkah yang memandu para pengembang pembelajaran, termasuk PBK, dalam desain kegiatan pembelajaran. Tahap I pada model ini disebut dengan definisi sistem. Tahap ini merujuk pada kegiatan awal yang harus direncanakan dan diorganisasikan sebelum terjadinya pengembangan materi pembelajaran.

Tahap II disebut dengan tahap pengembangan sistem. Dalam tahap ini, standar prestasi khusus, spesifikasi materi, dan batas desain dibuat. Tujuan perilaku yang tepat ditulis, dan seluruh prosedur pembelajaran didesain. Rencana pembelajaran ini disebut dengan prototipe karena rencana ini akan diuji dan direvisi di tahap III pendekatan sistem.

Tahap III merupaka prosedur evaluasi. Pada tahap ini, materi dan teknik pembelajaran yang disebut dengan prototipe dievaluasi dan direvisi. Proses revisi ini terus diletakkan sampai validitas sistem pembelajaran baru ditentukan. Garisgaris feedback menghubungkan semua tahap dalam proses. Dalam konteks pendekatan sistem, feedback merujuk pada informasi yang digunakan untuk membuat penyesuaian dalam materi dan prosedur pembelajaran.

\section{Teori Kognitif}

Para psikolog pendidikan dan ahli teori pembelajaran mulai beralih dari pendekatan behaviorisme dan menganjurkan untuk melihat lebih dekat ke dalam proses yang terjadi pada siswa selama pembelajaran. Para ahli behaviorisme mengabaikan perubahan kognitif yang terjadi di dalam proses pembelajaran dan tetap pada pendapat bahwa tidak mungkin bia mendasain pembelajaran berdasarkan atas kejadian yang terjadi di dalam otak siswa karena hal tersebut tidak bisa dilihat, diukur, dan diprediksi. Di sisi lain, para ilmuan kognitif, memberikan 
otonomi/kebebasan dan inisiatif yang lebih besar kepada siswa ${ }^{22}$

Teori koginitif berkonsentrasi pada koseptualisasi proses belajar siswa. Teori ini berfokus pada explorasi terhadap cara siswa dalam menerima,mengorganisasi, menyimpan, dan menggunakan informasi di dalam otak. Para pendukung teori ini percaya bahwa desain pembelajaran seharusnya memuat struktur kognitif siswa, dan kelompok siswa. Beberapa orang dianggap berjasa dalam perkembangan teori ini, termasuk di antaranya adalah Jerome Bruner, Jean Piaget, dan Seymour Papert.

\section{F. Penutup}

Media berasal dari kata "medium" yaitu perantara. Media pembelajaran adalah segala sesuatu benda atau alat yang dapat membantu seorang guru dalam menyampaikan suatu materi dengan mudah sehingga tercapai tujuan pembelajaran dengan optimal. Oleh karena itu media pembelajaran sangat penting dalam setiap proses pembelajaran sehingga tujuan

$\begin{array}{ccc}22 & \text { Azhar } & \text { Arsyad, }\end{array}$ Media

pembelajaran dapat tercapai dengan optimal.

Begitu juga halnya dengan pengembangan media untuk pembelajaran kosa kata bahasa Arab diperlukan usaha dari pendidik. Sebab, media merupakan sarana yang berpengaruh positif bagi keberhasilan untuk mencapai tujuan pembelajaran kosa kata bahasa Arab tersebut.

\section{Daftar Pustaka}

Abdul Gafur, Peranan Teknologi Pembelajaran dalamProses Belajar-Mengajar Ilmu Pengethuan Sosial. Pidato Pengukuhan Guru Besar dalam Bidang Ilmu Teknologi Pembelajaran Pengetahuan Sosial. Tidak di publikasikan, 2004

Ade Kusnandar, Evaluasi Multimedia Pembelajaran, Modul serial pelatihan pengembangan multimedia untuk pembelajaran. Jakarta: Pustekkom Diknas, 2000

Adi Kusrianto, Huruf display dengan komputer dan manual. Yogyakarta: Andi, 2005

AECT., The Definition of
Educational Technology :
AECT Task Force on
Definition and Terminology.
Washington, DC :


Associations for Educational Communications and Technology (AECT), 1997

Arief S. Sadiman, dkk., Media Pendidikan: Pengertian, Pengembangan, dan Pemanfaatannya. Jakarta: PT RajaGrafindo Persada, 2006

Azhar Arsyad, Media Pembelajaran, Jakarta: PT. Raja Grafindo Persada, 2002, Cet-3

Criswell, E.L., The design of computer-based instruction, New York: Macmilan Publishing Company, 1989

Dick, W., Carey, L., \& Carey, J.O., The systematic design of instruction $\left(5^{\text {th }} e d\right)$. New York: Longman, 2001

Gerlach, V.S, Ely, D.P., Teaching and media a systematic approach ( $\left.2^{\text {nd }} \quad e d\right)$. Englewood Cliffs, New Jersey : Prentice Hall Inc, 1980

Hanafin, M. J., Peck, The design development, and evaluation of instructional software. New York : Macmillan Publishing Company, 1988

Heinich, R., et al., Instructional media and technology for learning.Englewood Cliffts $\left(4^{\text {th }}\right.$ ed.). New Jersey: Prentice-Hall, Inc., A Simon \& Schuster Company, 1996

Kemp, J. E. \& Dayton, D. K., Planning and producting instructional media ( $4 t^{h}$ ed.). New York: Harper \& Row, Publisher, Inc., 1985

Nana Sudjana, Penilaian Hasil Proses Belajar Mengajar. Bandung : PT. Remaja Rosdakarya, 2002

Philips, R., Multimedia: A practical guide for educational application. London : Stirling (USA) : Kogen Page, 1997

Rose, Colin., K. U. A. S. A. I. Lebih Cepat. Di terjemakan oleh Syahrani Femmy. Bandung: Kaifa, 2002

Seels, B. B., \& Richey, R. C., Instructional technology: the definition and domain of the field. Washinton D.C.: Association for Educational Communication an Technology (AECT), 1994

Simonson, M.R \& Thompson, A., Educational Computing Foundations. New York : Macmillan Publish Company, 1994

Soenarto, S. \& Supriyadi E., .Relevanci pengembangan CAI dalam pendidikan. Cakrawala Pendidikan (Juni 2002.Th XXI. No.2), 2002

Walker. D. F. \& Hess, R.D., Instructional software: Principles and perspectives for design and use. San Francisco: Wadwort Publishing Company, 1984 